\title{
Rozvoj výzkumných kompetencí žák na základní škole: zkušenosti $z$ evaluace programu o Jizerských horách
}

\section{Jan Činčera}

Envigogika 2011/VI/3- Recenzované články/ Reviewed Papers

Publikováno/Published 31. 12. 2011

DOI: http://dx.doi.org/10.14712/18023061.63

\begin{abstract}
Abstrakt:
Článek prezentuje evaluaci vlivu programu střediska ekologické výchovy Jizerka na znalosti dětí o problému narušení lesních porostů $v$ Jizerských horách a na vybrané výzkumné dovednosti. Výzkum proběhl formou jednoduchého evaluačního designu typu pretest/posttest na vzorku 64 žáků ve věku 12-14 let. Podle výsledků program pozitivně ovlivňuje všechny měřené znalostní proměnné, malý vliv byl zaznamenán na schopnost žáků kriticky analyzovat texty o environmentálních problémech. V diskusi jsou navrhována opatření k další modifikaci programu.
\end{abstract}

\section{Klíčová slova:}

Evaluace, výzkumné dovednosti, analýza textu, Jizerské hory

\begin{abstract}
:
The article presents an evaluation of a programme of the environmental education centre Jizerka on pupils' knowledge of a problem of forests' degradation in Jizera mountains and on selected investigation skills. The research was based on a simple evaluation pretest/posttest design on a sample of 64 pupils 12-14 years old. According to the results, the programme positively influences all of the measured cognitive variables, although its impact on critical texts' analysis was only weak. In discussion, means for further programme modifications are suggested.
\end{abstract}

\section{Key words:}

Evaluation, research skills, texts' analysis, Jizera moutains 


\section{Úvod}

Jedním z cílů environmentální výchovy je i rozvíjení výzkumných dovedností dětí v oblasti analýzy environmentálních problémů a konfliktů (Hungerford, Peyton a Wilke, 1980). Výzkumné dovednosti, resp. dovednosti pro dotazování, analýzu a interpretaci, jsou jednou ze čtyř hlavních oblastí vymezených ve standardech Severoamerické asociace environmentální výchovy pro základní vzdělávání (NAAEE, 2004) a nově se objevují i $v$ českých Doporučených očekávaných výstupech pro prưřezové téma Environmentální výchova (Pastorová a kol., 2011). Podle nich by žáci na druhém stupni měli být napríklad schopni formulovat výzkumnou otázku a navrhnout metody jejího zodpovězení, shromažd'ovat, vyhodnocovat a prezentovat naměřená data (Pastorová a kol., 2011).

Řada autorů předpokládá, že osvojení výzkumných dovedností je jedním z předpokladů pro vytvoření zájmu dětí o environmentální problémy a konflikty a motivaci pro zapojení dětí do jejich řešení (Hungerford a Volk 1990; Bardwell, Monroe a Tudor 1994; Marcinkowski 2004; Winther 2005).

$\checkmark$ rámci environmentální výchovy děti rozvíjí své výzkumné dovednosti bud' v sociální, nebo přírodovědné oblasti. výzkumy v sociální oblasti jsou zpravidla zaměřené na analýzu environmentálních konfliktů. Děti zkoumají, jaké v daném konfliktu vystupují zainteresované strany, jaké zastávají postoje a z jakých hodnot jejich postoje vychází (Bardwell, Monroe a Tudor 1994; Marcinkowski 2004; Winther 2005). Prostřednictvím výzkumu si uvědomují, že konflikty o využívání území jsou přirozenou součástí demokratického života a rozvíjí kompetence potřebné k tomu, aby do nich mohli sami vstupovat a ovlivňovat rozhodovací procesy (Breiting a kol., 1999).

Př́rodovědně zaměřené výzkumy se zpravidla soustředí na výzkum environmentálních problémů. Děti zkoumají, do jaké míry se problém projevuje ve zkoumané lokalitě a jak ovlivňuje složky a procesy životního prostředí. Např́ílad v rámci pobytových programů sítě britských center Field Study Councils si děti vyberou téma (např. vliv znečištění vody na druhovou rozmanitost vodního hmyzu), naučí se formulovat hypotézu, určit plán výzkumu, sebrat a statisticky vyhodnotit data a následně zpracovat výzkumnou zprávu.

Společným rysem obou typů výzkumů je, že rozvíjí kritické myšlení dětí a jejich schopnost ptát se (Ernst a Monroe, 2004; Dori a Herscovitz, 1999). Bez ohledu na zaměření se děti učí procházet cestou vědeckého myšlení, které začíná kladením otázek, promyšlením plánu na jejich zodpovězení, respektováním stanovených procedur pro sběr a analýzu dat a kritickou reflexi naměřených zjištění.

V České republice představuje rozvíjení výzkumných dovedností na základních a středních školách problematickou oblast. Podle výsledků PISA studie sice čeští žáci mají rozsáhlé znalosti z biologie, ale nedokážou je aplikovat na problémy reálného světa (Palečková, 2007). Špatné výsledky mají i v testech vyhodnocujících jejich schopnost porozumění textu a jeho kritickému vyhodnocení (Palečková, 2010).

Domácí programy environmentální výchovy, které by komplexně rozvíjely výzkumné dovednosti žáků, jsou stále poměrně vzácné. $V$ programech nabízených středisky ekologické výchovy se sice často objevují prvky výzkumné metodiky, často ale jde pouze o sběr dat $v$ terénu (například monitoring druhové rozmanitosti) $\mathrm{s}$ následnou diskusí. O komplexní rozvoj výzkumných dovedností usilují např́klad programy 3V a GLOBE nabízené Sdružením TEREZA.

Program 3V je určený pro žáky středních škol. Jeho cílem je „přispět $k$ vědeckému způsobu uvažování založenému na předpokladech a faktech, a zvýšit tak atraktivitu vědeckých kariér pro mladou generaci." (Sdružení TEREZA, 2011a) Program kombinuje 
terénní práci $\mathrm{s}$ e-learningem. Žáci $v$ něm prochází celým procesem vědecké práce od formulování hypotéz až po prezentaci výsledků (Sdružení TEREZA, 2011a).

GLOBE je mezinárodní program, který rozvíji dovednosti dětí pro zkoumání životního prostředí (Sdružení TEREZA, 2011b). Zahraniční i domácí evaluace ale ukazují, že učitelé se $v$ rámci programu nejčastěji zabývají sběrem dat a zpravidla pomíjejí ostatní fáze výzkumného procesu. V důsledku sice program rozvíjí znalosti žáků o životním prostředí, ale nemá podstatnější vliv na jejich výzkumné dovednosti (Činčera a Mašková, 2011; Penuel a kol., 2006).

Jedním z programů, které usilují o komplexní rozvoj výzkumných dovedností u žáků je "Vyšetřování jizerskohorské katastrofy - pro 7. - 9. tř́du ZŠ" realizovaný střediskem ekologické výchovy Jizerka. Program byl zahájen na počátku sezóny v roce 2010. Po prvním roce byl evaluován v rámci práce Vlachová a Činčera (2011). Evaluace se zaměřovala především na vliv programu na znalosti o příčinách poškození lesů Jizerských hor. V rámci výzkumu ale nebyl podstatnější efekt programu naměřen. Program byl proto následně přepracován a v nové podobě zahájen od jara 2011. Následující text prezentuje metodiku a evaluaci upraveného programu.

\section{Popis programu}

Program Vyšetřování jizerskohorské katastrofy vznikl v rámci projektu "Člověk a krajina Jizerských hor" (reg. č. CZ.1.07/1.1.09/02.0061), který byl podpořen z Operačního programu Vzdělávání pro konkurenceschopnost. $\mathrm{Na}$ jeho vytváření spolupracovala Společnost pro Jizerské hory, o.p.s. a Technická univerzita v Liberci. Text prezentuje verzi programu určenou pro starší žáky, tedy 7. - 9. tř́du. Verze určená pro čtvrtý až šestý ročník sdílí s prezentovaným programem některé společné prostředky, ale má jiné cíle a priority.

Program seznamuje žáky s vývojem lesů $v$ Jizerských horách a rozsáhlým odlesněním, ke kterému došlo $v 80$. letech dvacátého století. Následně program rozvijí kompetence žáků související s výzkumem stavu lesů v okolí Jizerky.

Žáci uvedou nejméně tři různé lidské činnosti, které ovlivňují životní prostředí $v$ Jizerských horách. U každé vysvětlí, proč k ní dochází a jak mohou být její negativní důsledky zmírněny. Porovnají míru vlivu dané činnosti na životní prostředí Jizerských hor před rokem 1990 a v současnosti.

Očekávané výstupy programu:

Žáci...

- Analyzují současné i historické novinové články, vyberou z nich podstatné informace a odpovědi na předložené i samostatně formulované otázky.

- Vyberou správné indikátory zdravého lesa a připraví si plán jejich ověření $v$ terénu.

- Na základě vlastního měření vyhodnotí stav životního prostředí podle indikátorů relevantních pro zvolený environmentální problém. Výsledky pak souhrnně prezentují.

- Navrhnou postup/opatření jak se do budoucna vyhnout opakování podobné katastrofy lesů $v$ Jizerských horách nebo $v$ dalších srovnatelných lokalitách (Činčera, Kavan \& Šedlbauer, 2011).

Program se skládá ze dvou částí. První se odehrává ve škole a je řízena pomocí pracovních listů učiteli. Stejně jako u verze programu pro mladší žáky, jsou děti motivovány fiktivním rozhovorem mezi světoběžnicí Susan a pracovníkem střediska 
Dejvem na Facebooku. Susan se chce dozvědět více o přičinách odlesnění v Jizerských horách a Dejv, aby jí mohl odpovědět, prosí děti o pomoc se zpracováním výzkumu.

Jádro školní části tvoři práce s dobovými novinovými články. Žáci jsou postupnými kroky vedeni $k$ tomu, aby z článků získali odpovědi na položené otázky. $V$ průběhu se jednak učí porozumět př́činám environmentálního problému, jednak se zdokonalují ve schopnosti analyzovat krátké odborné či novinové texty. Důležitou rovinu tvoří i porovnání př́stupu k problému za totalitního režimu a po roce 1989.

V závěru školní fáze si děti mají ve skupinách připravit výzkumný plán, který by vedl k odpovědi na otázku Susan, zda v současné době jsou jizerskohorské lesy už zdravé. Žáci by měli promyslet tzv. indikátory výzkumu, tedy definovat data, která budou $v$ terénu sbírat a promyslet strategii jejich sběru a vyhodnocení. Současně jsou vybízeni k tomu, aby své plány podrobili kritické reflexi a uvědomili si jejich limity.

Druhou část programu tvoří tři či pětidenní pobyt na středisku Jizerka. Zde by žáci za pomoci lektorů měli realizovat svůj výzkum, tj. sebrat v terénu naplánovaná data, vyhodnotit je a prezentovat výsledek.

\section{Metodika evaluace}

Evaluace se zaměřuje na dvě hlavní otázky:

- Zvyšuje program porozumění problému narušení lesních porostů v Jizerských horách?

- Rozvíjí program vybrané výzkumné kompetence žáků?

Pro jejich zodpovězení byl připraven jednoduchý evaluační design typu pretest/posttest. Cílem bylo získat data od všech tříd, které v sezóně 2011 prošly programem. V průběhu roku se uskutečnilo pět turnusů programu z celkem šesti tříd tří různých škol z Libereckého kraje (tři paralelní třídy ze sedmého ročníku, dvě paralelní třídy z osmého ročníku a jedna tercie víceletého gymnázia, celkem 104 žáků. V praxi se podařilo získat dotazníky pouze od pěti tříd, které se účastnily čtyř třídenních turnusů programu. Tři z pěti trríd byly paralelní trrídy $(A, B$ a $C$ ) sedmého ročníku stejné základní školy. Na školní verzi programu se podíleli stejní učitelé. Žáci byli rozděleni do dvou navazujících turnusů. $Z$ tohoto důvodu je možné tyto třídy považovat za poměrně homogenní skupinu. Čtvrtou třídou ve vzorku byli žáci osmého ročníku jiné základní školy. Poslední třídou byli žáci tercie víceletého gymnázia.

Ze vzorku byli vyřazeni respondenti, které se nepodařilo spárovat (tj. dodali pouze pretest nebo posttest). Celkem se podařilo spárovat 64 respondentů:

\section{Tab. č. 1 Vzorek}

\begin{tabular}{|l|l|l|l|l|l|}
\hline $\begin{array}{l}\text { Celkový počet } \\
\text { účastníků } \\
\text { programu }\end{array}$ & $\begin{array}{l}\text { Počet žáků } \\
\text { ve vzorku }\end{array}$ & $\begin{array}{l}\text { Podíl vzorku } \\
(\%)\end{array}$ & Chlapců & Dívek & Věk \\
\hline 104 & 64 & 61.5 & 24 & 40 & 13,07 \\
\hline
\end{tabular}

Ve všech třídách byli o zadání pretestu požádáni učitelé, kteří se přihlásili do projektu. Od pracovníka střediska dostali připravené testy a instrukce pro jejich administraci. Test byl zadáván bezprostředně před zahájením práce na školní části programu. $V$ jedné z původně šesti zapojených škol bohužel učitel na zadání testu před 
začátkem práce s pracovními listy zapomněl a třída proto musela být vyřazena z výzkumu. Posttest byl zadáván na středisku lektorem po ukončení poslední aktivity programu. Přestože délka školní fáze se mohla na jednotlivých školách lišit, byl interval mezi pretestem a posttestem zhruba jeden měsíc.

Test se skládal ze čtyř hlavních částí:

- Demografické údaje (údaje pro spárování respondentů, pohlaví, věk, ročník, vztah k biologii, celkový prospěch).

- Porozumění problému (test, ve kterém žáci vybírali tři nejlepší z šesti odpovědí na otázku, které lidské činnosti nejvíce ovlivnily stav lesů v Jizerských horách v 80. letech dvacátého století a druhá část, kdy žáci mohli vybrat jednu či více možností z celkem pěti na otázku „která tvrzení o Jizerských horách jsou pravdivá").

- Analýza textu (Žáci dostali dva krátké novinové články, jeden z 80 . let a druhý ze současnosti. Jejich úkolem bylo vybrat správnou odpověd' ze čtyř možností na dvě otázky ke každému textu.)

- Stanovení indikátorů (Žáci měli navrhnout tři konkrétní věci, kterých by si mohli v lese všimnout a podle kterých by mohli poznat, zda okolní les je či není zdravý. Své návrhy vpisovali do nedopsaných vět ve formátu "Ve zdravém lese ...., zatímco $v$ narušeném..."). Jizerka.

Obsahová validita testu byla konzultována s koordinátorem programu ze SEV

Část porozumění problému byla bodována na škále $<-6 ;+6>$. Za každou špatnou vybranou odpověd' respondent získal záporný bod, za správnou kladný. Správné odpovědi $v$ analýze textu byly hodnoceny kladným bodem. Zák tedy mohl získat 0-4 body. Správnost navržených indikátorů byla posuzována případ od př́padu. Za uvedení relevantního indikátoru respondent získal bod. Celkem tedy žáci mohli získat 0-3 body.

Statistická významnost rozdílů mezi pretestem a posttestem byla hodnocena pomocí znaménkového testu při $a=0,05$. Protože vzorek byl poměrně malý a hrozilo proto riziko chyby druhého typu, byla $v$ prípadě výsledku těsně nad hladinou významnosti provedena kontrolní kalkulace pomocí Wilcoxonova párového testu. Pomocné kalkulace vyhodnocující vztah vybraných demografických proměnných na ostatní sledované proměnné byl hodnocen pomocí Kruskal-Wallisovy ANOVA testu a Spearmanova korelačního koeficientu. Velikost efektu byla vypočtena jako podíl hodnoty $Z$ znaménkového testu a druhé odmocniny počtu respondentů.

Výsledky jsou dále doplněny o nestrukturované pozorování lektorů v průběhu pobytové části programu.

\section{Prezentace výsledků implementace programu}

Podle výpovědi lektorů hodnotí učitelé, kteří doprovází třídu na pobytovou část, program jako značně rozsáhlý a náročný. Za nejtěžší pak považují poslední část školní fáze, ve které si děti mají naplánovat výzkum na Jizerce. Žádná ze tříd ve vzorku neměla tuto fázi kompletně připravenou.

Podle názoru koordinátora programu představuje výzkumná problematika pro učitele nové téma. Učitelé mu sami dobře nerozumí a nedokážou jej proto se žáky probrat. Tím, že je př́prava výzkumu zařazena až na závěr školní fáze, se pak často nestihne, případně se jí učitelé záměrně vyhnou: 
"Učitel má dost starostí sám se sebou, aby problematiku pochopil, natož aby ji dokázal předat. Hodně učitelư (zejména starších) se odmítá již věnovat něčemu novému a měnit svůj zaběhnutý styl, proto si mnohdy pracovní listy zjednoduší a s žáky je "udělají", ale tak, jak nechceme. Většina 7.-9. tříd je navíc ochuzena o tahouny, kteří odešli již dř́ve na víceletá gymnázia, takže pro mnohé žáky je to daleko za hranicí jejich možností, a to $i v$ případě, že to děláme na Jizerce. Světlou výjimkou jsou ročníky víceletých gymnázií, kde by to mohlo v budoucnu fungovat."

Lektoři se proto přípravě výzkumu věnují první den pobytu ve středisku. To je ale komplikováno skutečností, že školy si vybírají raději třídenní verzi programu (všechny školy ve vzorku absolvovaly tuto verzi). Uváděnými důvody jsou zejména neochota učitelü absolvovat s žáky celý týden, případně omezení ze strany vedení školy. Jedním z důvodů je ale i snaha střediska nabídnout program co největšímu počtu škol. Středisko proto umožňuje každé škole zúčastnit se bud' dvakrát třídenní verze, nebo jednou pětidenní verze programu. $V$ důsledku ale není na rozvíjení souvisejících výzkumných dovedností dostatek času. Děti dorazí na oběd, odpoledne si připravují výzkum, druhý den dopoledne sbírají data, odpoledne připravují prezentaci a večer prezentují. Třetí den dopoledne pak uzavírají program a odjíždí.

\section{Efekt programu na sledované proměnné}

První část testu zkoumala rozdíl odpovědí na otázky týkající se porozumění problému poškození lesních porostů v Jizerských horách mezi pretestem a posttestem.

Tab. č. 2 Porozumění environmentálnímu problému

\begin{tabular}{|l|l|l|l|l|l|l|}
\hline & Počet & Průměr & $\begin{array}{l}\text { Směrodatná } \\
\text { odchylka }\end{array}$ & $\begin{array}{l}\text { Z } \\
\text { (znaménkový } \\
\text { test) }\end{array}$ & ES & $\begin{array}{l}\text { P } \\
\text { (znaménkový } \\
\text { test) }\end{array}$ \\
\cline { 1 - 5 } Před & \multirow{2}{*}{64} & 0,09 & 1,84 & 5,66 & 0,7 & $<0.000$ \\
\cline { 3 - 6 } & 2,23 & 1,83 & 50 & \\
\hline
\end{tabular}

Poznámka: ES =effect size, velikost efektu

Lze říct, že postest odráží statisticky významné zvýšení znalostí měřené testem. Efekt programu je možné hodnotit jako velký.

Tab. č. 3 Porovnání odpovědí po jednotlivých položkách

Položka

\begin{tabular}{|l|l|l}
$\begin{array}{l}\text { Vybralo } \\
\text { PRED }\end{array}$ & VObralo & \\
$(\%)$ & $(\%)$ & P
\end{tabular}

Vyber tři lidské činnosti, které podle Tvého názoru nejvíce ovlivnily stav lesů v Jizerských horách v 80. letech 20. století (zakroužkuj tři možnosti):

\begin{tabular}{|l|l|l|l|}
\hline Spalování sirnatého uhlí v tepelných elektrárnách. & 72 & 92 & $0,003^{*}$ \\
\hline Neukázněné chování turistů a motorkářů. & 41 & 15 & $0,002^{*}$ \\
\hline Výstavba turistických chat a sjezdovek. & 31 & 5 & $<0.000 *$ \\
\hline Vysazování nepůvodních druhů stromů. & 39 & 75 & $<0.000 *$ \\
\hline
\end{tabular}




\begin{tabular}{|c|c|c|c|}
\hline Lov ohrožených zvířat pytláky. & 58 & 41 & 0.052 \\
\hline Těžba stromů napadených kůrovcem. & 48 & 69 & $0.02 *$ \\
\hline \multicolumn{4}{|c|}{ Která tvrzení o Jizerských horách jsou pravdivá (müžeš zakroužkovat více možnosti):? } \\
\hline $\begin{array}{l}\text { Stav lesů v Jizerských horách se posledních čtyřicet let stále } \\
\text { zhoršuje. }\end{array}$ & 45 & 9 & $<0.000 *$ \\
\hline $\begin{array}{l}\text { Pro stabilizaci lesních porostů se v posledních deseti letech } \\
\text { začaly vysazovat zahraniční druhy odolných smrků. }\end{array}$ & 42 & 44 & 0.85 \\
\hline $\begin{array}{l}\text { Díky odsíření tepelných elektráren se podařilo snížit } \\
\text { kyselost půdy a vodních toků v Jizerských horách. }\end{array}$ & 58 & 84 & $0.001 *$ \\
\hline $\begin{array}{l}\text { Ve srovnání s } 80 \text {. lety žije nyní v Jizerských horách více } \\
\text { rybích druhů. }\end{array}$ & 34 & 37.5 & 0.61 \\
\hline V Jizerských horách dnes již „mrtvé lesy” prakticky nejsou. & 23 & 34 & 0.17 \\
\hline
\end{tabular}

Poznámka: správné odpovědi jsou ztučněny. $P$ udává pravděpodobnost náhodného vzniku rozdílu při chí kvadrát testu. Hvězdička udává statistickou významnost při $a=0,05$.

V sedmi z jedenácti tvrzení došlo ke statisticky významnému posunu směrem ke správné odpovědi. U žádného tvrzení nedošlo ke statisticky významnému posunu směrem ke špatné odpovědi.

Celkově Ize říct, že rozdíl mezi pretestem a posttestem je statisticky významný. Je zjevné, že výsledek odráží velmi podstatné zvýšení porozumění problému narušení lesů v Jizerských horách.

Ve druhé části test měřil schopnost respondentů najít správné odpovědi na otázky k článkům o problému Jizerských hor.

Tab. č. 4 Analýza textu

\begin{tabular}{|l|l|l|l|l|l|l|l|l|}
\hline & Počet & Průměr & $\begin{array}{l}\text { Směrodatná } \\
\text { odchylka }\end{array}$ & $\begin{array}{l}\text { Z } \\
\text { (znaménkový } \\
\text { test) }\end{array}$ & $\begin{array}{l}\text { (znaménkový } \\
\text { test) }\end{array}$ & ES & $\begin{array}{l}\text { Z } \\
\text { Wilxocon }\end{array}$ & $\begin{array}{l}\text { Wilcoxon } \\
\text { Před }\end{array}$ \\
\cline { 3 - 8 } & 64 & 2,15 & 1,25 & 1,6 & 0,1 & 0,2 & 2,05 & 0,04 \\
\cline { 3 - 8 } & 2,48 & 1,11 & & & &
\end{tabular}

Poznámka: ES=effect size, velikost efektu.

Výsledek v tomto př́padě není zcela průkazný. Přestože došlo ke zlepšení výsledků, rozdíl je statisticky významný podle Wilcoxonova párového testu, ale nikoliv podle znaménkového testu. To Ize interpretovat tak, že efekt programu byl poměrně slabý na hranici statistické významnosti.

$\checkmark$ poslední části žáci navrhovali indikátory, podle kterých by mohli vyhodnotit zdraví lesa. Lze říct, že návrhy $v$ pretestech odrážely zpravidla: skládka")

Znečištění odpadky („ve zdravém lese nejsou žádné odpadky...ve znečištěném je 
Estetická kritéria („je čisto...je špína", „je cítit vůně dřeva”; "rostou hezčí stromy...rostou hnusné stromy")

Tautologické odpovědi ("ve zdravém lese stromy vypadají zdravě, nemají poničený kmen...v narušeném mají stromy oloupaný kmen a vypadají nemocně"; "jsou stromy zdravé...jsou poškozené"; "se zdravě žije...se nemocně žije")

Absolutní kritéria („Jsou zvířata ... nejsou zvířata"; „na zemi leží jenom větve"; „běhají zvířata...nenajde se ani houba"; "sou živočichové...sou zlý lidé"; "jsou zdravá zvířata...nejsou"; "nejsou stromy napadené škưdci...ano")

Jiná částečně či zcela nesouvisející kritéria ("ve zdravém lese je pořád tma... v narušeném svítí pořád sluníčko" "čerstvý vzduch...naopak", "je více lesních plodư"; "rostou houby...jenom málo"; "ve zdravém lese nejsou suché klacky", "neporušená mraveniště a hnízda ... je vše rozkopáno a zničeno"; "by nebyly emise z aut...je hodně emisí"; "turisti se k lesu chovají líp...tam házeli odpadky)

V posttestech se pak kromě chybných objevovaly i správné indikátory, vyjadřující:

Vyšší druhovou rozmanitost („ve zdravém lese je více druhů stromů...v narušeném jsou monokultury")

Rozdíly ve věkové skladbě stromů („jsou různě staré stromy...jsou stejně staré")

Relativní rozdíl v četnosti suchých či poškozených stromů („téměř nejsou suché stromy...je jich více")

Relativní rozdíl v míře napadenosti stromů („není mnoho stromů napadených...jich je napadených více") je")

Narušení populační dynamiky zvěře („není přemnožená vysoká zvěř...přemnožená

Celkově Ize říct, že se v posttestech žáci posunuli od absolutních kritérií k relativním, vyjadřující rozdíly $v$ míře určitého jevu, opustili některé nesouvisející indikátory a přijali nové.

Tab. č. 5 Stanovení indikátorů

\begin{tabular}{|c|c|c|c|c|c|c|}
\hline & Počet & Průměr & $\begin{array}{l}\text { Směrodatná } \\
\text { odchylka }\end{array}$ & $\begin{array}{l}\text { Z } \\
\text { (znaménkový } \\
\text { test) }\end{array}$ & ES & $\begin{array}{l}\text { P } \\
\text { (znaménkový } \\
\text { test) }\end{array}$ \\
\hline Před & \multirow{2}{*}{64} & 0,32 & 0,59 & \multirow{2}{*}{5,57} & \multirow{2}{*}{0,69} & \multirow{2}{*}{$<0.000$} \\
\hline Po & & 1,43 & 1,15 & & & \\
\hline
\end{tabular}

Poznámka: ES=effect size, velikost efektu.

Rozdíl mezi pretestem a posttestem je statisticky významný. Na konci programu byly děti schopny uvést více správných indikátorů zdravého lesa, než na jeho začátku. Naměřený efekt můžeme hodnotit jako velký.

Z dalších faktorů má vliv zejména skupina, ve které respondent program absolvoval. $\checkmark$ rámci výzkumu byli žáci ze sedmé $A, B$ a $C$ stejné základní školy spojeni do jedné skupiny. Posuzovány byly tedy rozdíly mezi třemi skupinami. 
Tab. č. 6 Porovnání skupin

\begin{tabular}{|l|l|l|l|l|l|l|l|}
\hline Skupina & \multicolumn{2}{|l|}{$\begin{array}{l}\text { Počet } \\
\text { žáků }\end{array}$} & \multicolumn{2}{l|}{ Porozumění problému } & \multicolumn{2}{l|}{ Analýza textu } & \multicolumn{2}{l|}{ Stanovení indikátorů } \\
\hline & & PŘED & PO & PŘED & PO & PŘED & PO \\
\hline 7. třída & 28 & 0,28 & 2,1 & 1,89 & 2,07 & 0,1 & 0,92 \\
\hline 8. třída & 14 & $-1,14$ & 0,21 & 1,85 & 2,14 & 0,57 & 0,71 \\
\hline Tercie & 22 & 0,63 & 3,68 & 2,68 & 3,22 & 0,45 & 2,54 \\
\hline
\end{tabular}

Členství ve skupině má vliv na všechny sledované proměnné: porozumění problému $v$ posttestu (Kruskal-Wallisova ANOVA $H=31,59 p<0.00$ ), porozumění textu ( $H=15,86$, $p=0,0004)$, stanovení indikátorů výzkumu $(H=31,48, p<0.00)$. To Ize interpretovat dvěma způsoby. Prvním je vliv učitele a jeho podíl na implementaci školní části programu. Druhým mohou být rozdíly mezi jednotlivými školami.

Dílči vliv na výsledky mělo také pohlaví respondenta. Ten se projevil $v$ analýze textu $v$ posttestu, kde průměrný bodový zisk chlapcủ byl $\mathrm{m}=2,95, \mathrm{SD}=1,08$, dívek $\mathrm{m}=2,2$, $\mathrm{SD}=1,04$ (Kruskal-Wallisova ANOVA $\mathrm{H}=7,01 \mathrm{p}=0,08$ ). Vzhledem k malé velikosti vzorku ale nelze tento výsledek zobecňovat.

Porozumění problému, analýza textu a stanovení indikátorů spolu navzájem statisticky významně korelují. Prospěch ani vztah k biologii se ve výsledcích podstatně neodrazily.

\section{Diskuse}

Vzhledem k malé velikosti vzorku nelze výsledky přeceňovat. Zdá se ale, že program u cílové skupiny účinně rozvíjí porozumění problému poškození lesních porostů v Jizerských horách a rozšiřuje její znalost indikátorů zdravého lesa. Vliv programu na schopnost žáků analyzovat články o environmentálním problému je spíše malý a na hranici statistické významnosti. Pro interpretaci tohoto výsledku je dále třeba zvážit, že sledovaný dovednostní cíl mohl být ovlivněn větším porozuměním respondentů problematice, o které analyzované články referovaly.

Bariérou většího efektu programu je implementace, která neprobíhá zcela podle předpokladů. Realizátoři by pravděpodobně měli zvážit, zda program nabízet ve zkrácené variantě, prípadně tuto volbu podmínit zvládnutím celé školní části programu. Je ale otázka, zda školy potom o něj budou mít zájem.

Před zahájením programu byly znalosti žáků o Jizerských horách a jejich porozumění problematice narušení lesních porostů poměrně nízké a deformované různými miskoncepty. To koresponduje s mezinárodními výzkumy, podle kterých je pro názory dětí a mládeže na environmentální konflikty typický značný zmatek a představy neodpovídající současnému stavu poznání (Rickinson, 2001). Děti mísí různé environmentální problémy dohromady (poškození lesních porostů a znečištění lesa odpadky), případně neadekvátně směšují různé druhy poškozování životního prostředí a přisuzují mu nesprávné dopady (emise vzniklé spalováním uhlí, emise $z$ automobilové dopravy, znečištění lesa odpadky) (Pruneau, Gravel, Butque \& Langis, 2003). Žáci typicky uvažují v absolutních kategoriích „všichni-nikdo" a neuvědomují si, že problémy nevznikají pouhou prítomností určitého jevu, ale jeho intenzitou a překročením míry schopnosti ekosystému se na něj adaptovat. Velké procento dětí dále předpokládalo, že stav životního prostředí v Jizerských horách se stále zhoršuje. To Ize srovnat s mezinárodními výzkumy, podle kterých děti zpravidla považují environmentální problémy za velmi závažné a jejich vývoj hodnotí pesimisticky 
(Rickinson, 2001). Provedená evaluace ale také podpořila předpoklad, že i v českém prostředí může být zapojení žáků do samostatného výzkumu účinným prostředkem k presnějšímu a vědecky adekvátnějšímu porozumění environmentálním problémům (Pruneau a kol., 2009).

Poměrně malý vliv programu na rozvíjení schopnosti kritické analýzy textu může souviset s celkově nízkou hladinou zvládnutí této kompetence českými žáky (Palečková, 2010). Je možné, že aby program $\vee$ této oblasti zaznamenal větší efekt, musel by se jí zabývat $v$ mnohem větší míře, prípadně ve větší součinnosti s další školní výukou. $Z$ testu pro tuto domněnku ale nemůžeme najít dostatečně silnou oporu.

Druhý důvod může souviset s chybami v implementaci školní části programu, které nebyly výzkumem odhaleny. Modelová sekvence pro výuku dovedností zahrnuje demonstraci rozvíjené dovednosti, její procvičení, poskytnutí zpětné vazby a následnou praktickou aplikaci. Klíčovým prvkem pak je fáze opakovaného procvičování a simultánního poskytování zpětné vazby (Heimlich a Ardoin, 2008). Pro procvičování kritické analýzy textu je proto zásadní věnovat se ve školní fázi programu dostatečně dlouho rozboru přiložených článků. Je možné, že učitelé nepostupují zcela podle pokynů pro rozbor uvedených textů a nedávají žákům pro procvičení dostatečný prostor, případně nedostatečně poskytují žákům potřebnou zpětnou vazbu. Tuto teorii by mohla ověřit kvalitativní evaluace založená na pozorování implementace programu ve třídách.

Je možné, že by upevnění této dovednosti pomohlo zařazení navazujícího aplikačního úkolu, ve kterém by žáci samostatně vyhledávali dokumenty o stavu jizerskohorských lesů a propojili je se svým výzkumem.

Evaluace dále ukázala, že mezi školami ve vzorku jsou velké rozdíly jak na začátku, tak na konci programu. To pravděpodobně odráží dva faktory. Prvním je reálnost rozdílů mezi jednotlivými typy škol. I ve výzkumu české verze programu GLOBE (Činčera a Mašková, 2011) se objevily velké rozdíly mezi výsledky žáků stejného věku ze základních škol a víceletých gymnázií. Druhým vysvětlením jsou rozdíly v implementaci programu na jednotlivých školách. Pro posílení pravděpodobnosti, že tato fáze proběhne ve shodě s očekáváním, by bylo asi vhodné zvážit možnosti pro posílení metodické podpory zapojených učitelů. Je možné, že by úspěšnost přípravy žáků na navazující sběr dat ve středisku pomohlo zvýšit, kdyby se realizátor $v$ rámci metodické podpory zaměřil na poslední fázi školní části programu, ve které žáci připravují plán výzkumu. Navazující výzkum by mohl vnést více světla do toho, proč školy tuto část zpravidla vynechávají. Pokud by se potvrdila domněnka koordinátora programu, mohlo by krátké školení pedagogů v základech výzkumných dovedností pomoci podstatně zvýšit efektivitu celého programu.

Jestliže výzkumné dovednosti jsou jednou z klíčových oblastí programu, bylo by dobré se na ně zaměřit $\mathrm{i} v$ dalších evaluačních šetřeních. Evaluace de facto ověřovala pouze malou část kompetencí souvisejících s výzkumem. Bylo by proto zajímavé zjistit, zda program např́klad ovlivnil schopnost navrhovat vhodné indikátory i pro jiné výzkumné otázky či zda a jak ovlivnil schopnost dětí zpracovat, analyzovat a prezentovat naměřená data.

V neposlední řadě by bylo možné zkoumat vliv programu na afektivní proměnné, jako jsou postoje k ochraně př́rody či vztah k Jizerským horám a ochota je navštěvovat. 


\section{Literatura}

- Bardwell, L.V.; Monroe, M.C.; Tudor, M.T.1994. Environmental Problem Solving. Theory, Practice and Possibilities in Environmental Education. Troy: NAAEE, 1994. ISBN 1-884-00813-5.

- BReiting, S.; HedegaARD, K.; MOGENSEN, F.; NIELSEN, K.; SCHNACK, K. Action comepetence, Conflicting interests and Environmental Education [online]. Aaarhus University, Research Programme for Environmental and Health Education, 1999. <Cit. 2011-11-12>. Dostupné na WWW <http://wWW.MUVIN.net>

- ČINČERA, Jan; MAŠKovÁ, Veronika. GLOBE in the Czech Republic: a program evaluation. Environmental Education Research. Roč. 17, 2011, n. 4, s. 499-517.

- ČINČERA, Jan; KAVAN, David; ŠEDLBAUER, Josef. Program Vyšetřování jizerskohorské katastrofy pro 7.-9. tř́du ZŠ. [pracovní listy]. Liberec: Společnost pro Jizerské hory, 2011.

- Dori, Y. J. \& Herscovitz, O.1999. Question-Posing Capability as an Alternative Evaluation Method: Analysis of an Environmental Case Study. Journal of Research in Science Teaching, vol. 36, no. 4, pp.411-430.

- $\quad$ Ernst, J.A.; Monroe, M.2004. The effects of environment-based education on students'

- $\quad$ critical thinking skills and disposition toward critical thinking. Environmental Education

- $\quad$ Research 10, no. 4: 507-22

- Heimlich, J.E. ; Ardoin, N.M.2008. Understanding behavior to understand behavior change: a literature review. Environmental Education Research, Vol. 14, no. 3, p. 215-237.

- Hungerford, H. R., Peyton, B. R.; WILKE, R.1980. Goals for Curriculum Development in Environmental Education. The Journal of Environmental Education. Vol. 11, Iss. 3, p. 42-47. ISSN 0095-8964.

- Hungerford, H. R. ;Volk, T. L.1990. Changing Learner Behavior Through Environmental Education. The Journal of Environmental Education, Vol. 21, Iss. 3, p. 8-21. ISSN 0095-8964.

- Marcinkowski, T. 1997. Assessment in Environmental Education. In Wilke, R. Environmental education teacher resource handbook: a practical guide for K-12 environmental education. Thousand Oaks: Corwin, 1997. ISBN 0-8039-6370-X.

- NAAEE. 2004. Excellence in Environmental Education: Guidelines for Learning (Pre K-12) Executive Summary \& Self Assessment Tool. Washington: NAAEE, 2004.

- Penuel, W. R., Bienkowski, M., Gallagher, L., Korbak, C., Sussex, W., Yamaguchi, R. \& Fishman, B. J.2006. GLOBE Year 10 evaluation: Into the next generation. Menlo Park, CA: SRI International, 2006. Dostupné z WWW <http://www.globe.gov/fsl/evals/y10full.pdf>

- PALEČKOVÁ, Jana; TOMÁŠEK, Vladislav; BASL, Josef. 2010. Hlavní zjištění výzkumu PISA 2010. Umíme ještě čist? Praha: Ústav pro informace ve vzdělávání, 2010. ISBN 978-80-211068-6.

- PALEČKOVÁ, Jana a kol. Hlavní zjištění výzkumu PISA 2006. Poradí si žáci s přirodními vědami? Praha: Ústav pro informace ve vzdělávání, 2007. ISBN 978-80-211-0541-6

- PASTOROVÁ, Markéta a kol. 2011. Doporučené očekávané výstupy. Metodická podpora pro výuku průřezových témat na základních školách. Praha: Výzkumný ústav pedagogický, 2011. Dostupné z WWW http://www.vuppraha.cz/nova-publikace-divize-vup-\%E2\%80\%93doporucene-ocekavane-vystupy-pro-zakladni-skolyISBN 978-80-87000-76-2.

- Pruneau, Diane; Gravel, Helene, Butque, Wendy, Langis, Joanne. 2003. Experimentation with a Socio-constructivist Process for Climate Change Education. Environmental Education Research, 2003, vol. 9, no 4, s. 429-446. ISSN 1350-4622. 
- $\quad$ PRuneau, D.; FReiman, V.; BARBieR, P.-Y.; LenGIS, J. 2009. Helping Young Students to Better Pose an Environmental Problem. Applied Environmental Education and Communication, 2009, vol. 8, p. 105-113.

- RICKINSON, M. 2001. Learners and Learning in Environmental Education: A critical review of the evidence. Environmental Education Research, 2001, vol. 7, no. 3, p. 207-320.

- Sdružení TEREZA. 2011a Projekt 3V - vědě a výzkumu vstř́c! [online]. <Cit. 2011-11-16>. Dostupné z WWW < http://www.projekt3v.cz/informace-o-projektu.html>

- Sdružení TEREZA. 2011b. GLOBE - mezinárodní eko-program [website]. <Cit. 2011-11-16> Dostupné z WWW <http://globe.terezanet.cz>

- VLACHOVÁ, Eva. 2011. Evaluace pobytových programů environmentální výchovy Společnosti pro Jizerské hory. [Diplomová práce]. Vedoucí práce Jan Činčera. Liberec: Technická univerzita, 2011.

- Winther,A. A. 2005. Investigating and Evaluating Environmental Issues and Actions (An Instructional Model for Environmental Education). In Hungerford, H.R., Bluhm, W.J., Volk, T.L., Ramsey, J.M. Essential Readings in Environmental Education. Champaign: Stipes, 2005. P. 173-196. ISBN 1-58874-496-8.

- Vlastní pozorování a ústní sdělení Martyn Jamieson, Field Study Council Kindrogan, 1.11.2011. 
Časopis Envigogika vydává Centrum pro otázky životního prostředí UK. Vývoj časopisu je podpořen projektem OP VK Mezioborová sít udržitelného rozvoje.

Více najdete na internetových stránkách projektu mosur.czp.cuni.cz
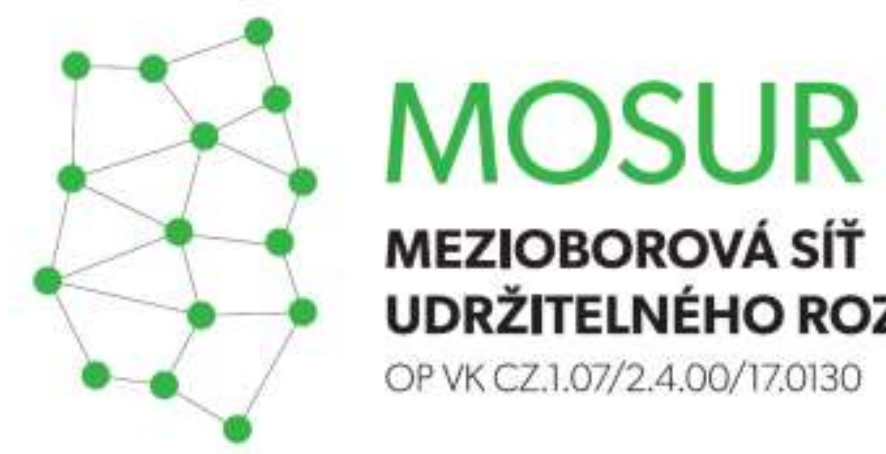

\section{MEZIOBOROVÁ SÍT} UDRŽITELNÉHO ROZVOJE

OP VK CZ.1.07/2.4.00/17.0130
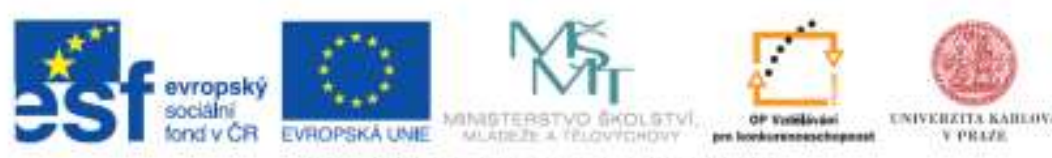

INVESTICE DO ROZVOJE VZDELAVANI 